\title{
Analysis of Mechanical and Metallographic Properties on The Joining Between Aluminum and Brass by Using The Brazing Method
}

\author{
Agus Dwi Anggono ${ }^{*}$, Nanang Ernawan ${ }^{2}$, Tri Widodo Besar Riyadi ${ }^{3}$ \\ ${ }^{1,2,3}$ Master of Engineering Program, Universitas Muhammadiyah Surakarta \\ J1. A. Yani, Pabelan Surakarta Indonesia 57162 \\ *ada126@ums.ac.id
}

\begin{abstract}
The objectives of this research is to investigate the tensile strength and structure of metallography of the metal connection between aluminum and brass by the brazing method. The type of joining is the but joint using an alusol filler. Specimens were made according to ASME IX standards. The ASTM E8 standard was used to tensile test. The macro and micro photos was carried out using ASTM E407-07. A joint with a shear area of $350 \mathrm{~mm}^{2}$ was broken when pulled with a load of $4.410 \mathrm{kN}$. The highest stress, strain and Young modulus was $12.601 \mathrm{~N} / \mathrm{mm}^{2}, 0.11$ and $1.183 \mathrm{kN} / \mathrm{mm}^{2}$ respectively. The porous microstructure was seen in the weld area facing to the brass material. The chemical composition of the specimens consisted of $\mathrm{C}$ $21.53 \%, \mathrm{Al}_{2} \mathrm{O}_{3} 37.20 \%, \mathrm{CuO} 13.63 \%$, and $\mathrm{ZnO} 27.64 \%$ from the EDX results.
\end{abstract}

Key words: brazed, aluminum, brass, alusol, tensile, micro structure.

\section{INTRODUCTION}

In the industrial world which is related to metals, there are many metal joining processes. One of the processes of joining two metal parts is by welding, that is connecting two or more metal parts permanently by using heat energy.

A part of welding science that is very important in the world of metal joining industry is brazing. Brazing is the joining of metals by heat distribution and the use of filler metals - which have a melting temperature above $840^{\circ} \mathrm{F}$ $\left(450^{\circ} \mathrm{C}\right)$ but below the joining metal melting point. Brazing has many advantages. Brazed ties are solid. The tensile strength of properly formed joints in non-ferrous metals and steels also exceeds that of joined metals. In stainless steel, joints with a strength of 130,000 pounds per square inch can be formed $(896.3 \mathrm{MPa})$. Brazed joints are ductile and can withstand substantial shocks and vibrations. Brazed connections are fast and easy to make, according to operator skills. Brazing can combine different materials. It can easily combine between iron and nonferrous metals, and materials with very various melting points. Brazing is basically a simple operation process. There is seldom a need to grind, filling or mechanical finishing after the connection is complete. Brazing takes place at relatively low temperatures, which eliminates the risk of the joining metal being bent, overheated or melted [1].

Aluminum has lighter and cheaper properties, while titanium offers very strong corrosion-resistant properties but the price is expensive. To combine the advantages of the two materials, a hybrid Ti-Al structure was tested. The joint was successfully carried out using brazing for aircraft seat passage applications [2].

Induction brazing to connect brass material and fair steel is carried out using Ag-Cu-Zn-Sn fillers [3]. In that study successfully formed a homogeneous micro structure and zero defects in the connection. The brazed layer thickness was around $75 \mu \mathrm{m}$.

Brazed joints are used in steel coatings with aluminum alloy strips. Steel cores provide material strength, especially at high temperatures, while aluminum alloys provide corrosion resistance. The brazing process is carried out with NOCOLOK filler material with variations in temperature and time [4].

The main problem with the brazing connection is the formation of an intermetallic layer. The brazing process for the joining of copper material was successfully carried out using ultrasonic without material filler at $420^{\circ} \mathrm{C}$. The ultrasonic brazing time is done for 5 seconds. The brazing results were tested by intermetallic layer of $\mathrm{Cu}$ substrate with $\mathrm{Zn}_{4} \mathrm{Al}$ and $\mathrm{Cu}$ with $\mathrm{Zn}_{6} \mathrm{Al}_{6} \mathrm{Ag}$. The results found intermetallic layers of $\mathrm{CuZn}_{4}$ and $\mathrm{Cu}_{5} \mathrm{Zn}_{8}$ formed at the $\mathrm{Cu}$ / $\mathrm{Zn}_{4} \mathrm{Al}$ boundary. At the $\mathrm{Cu} / \mathrm{Zn}_{6} \mathrm{Al}_{6} \mathrm{Ag}$ boundary there are intermetallic layers of $\mathrm{AgZn}_{3}$ and $\mathrm{Cu}_{5} \mathrm{Zn}_{8}$. The shear strength of the $\mathrm{Cu} / \mathrm{Zn} 4 \mathrm{Al}$ junction is $34.5 \mathrm{MPa}$ and the shear strength of $\mathrm{Cu} / \mathrm{Zn}_{6} \mathrm{Al}_{6} \mathrm{Ag}$ is $39 \mathrm{MPa}$. The results also showed that the brazing melting temperature was $404.9{ }^{\circ} \mathrm{C}$ and $396.9{ }^{\circ} \mathrm{C}$ [5]. Another researcher was used $\mathrm{NH} 2$ on PC61BM properties using density functional theory (DFT) [6].

Increasing the strength of the brazing joints between $\mathrm{Al}$ 3003 and $\mathrm{Zn}$ is done by reducing the thickness of the $\mathrm{Zn}$ layer and increasing the brazing holding time at high 
temperatures. Zn layer thickness and brazing time affect the strength of the joint. Microstructure and fracture analysis at the $\mathrm{Al} 3003$ / Zn brazing junction shows fragile material in the brazed area [7].

The brazing process can also be done by using a laser as a heat source. Material filler that is placed between the material is heated using a laser. Increasing the strength of the $\mathrm{Mn}$ material connection with silver metal filler material (Ag-40Cu-0.1Ni-0.3Ti) is done using $0.1 \mathrm{~mm}$ gab. The shear strength was tested according to AWS C3.2: 2001 standard. Micro photographs show the occurrence of penetration reactions and void connection defects that can affect shear strength [8].

A strong and stable oxide layer on the surface of the aluminum alloy. This inhibits the wetting ability in the process of melting the filler material. To address this, the brazing process is conducted using chemically active chloride-containing fluxes such as $\mathrm{NaCl}, \mathrm{KCl}, \mathrm{LiCl}$ and a small amount of fluoride. Aluminum alloys are commonly used for heat transfer materials due to their good thermal conductivity and corrosion resistance..

Aluminum brazing is a method used to combine a metal part with an aluminum part by using a liquid alloy material that has a lower melting point than aluminum. Removal of the oxide layer on the surface of the material can be carried out with the application of a suitable flux material to dissolve the oxide layer, simultaneously protecting against the formation of the oxide layer during the heating process. $\mathrm{CO}_{2}$ laser beams can be used as a heat source that produces fast local surface melting [9].

Research on the flux reaction when used for brazing aluminum material with steel has been carried out by researchers. High temperature salt flux from K, Al, Si / F can improve the wetting and capillary properties of filler metals during brazing. The aluminum brazing process using reactive fluxes can be done without a metal filler. Brazed joints in aluminum have the same strength as base metals, and the connection between aluminum and steel can maintain performance after a thermal cycle test. Flux reactions can occur due to heating from induction or arc. Polyatomic alcohol-based low temperature flux, which contains a synthesized metal tetra fluoroborate complex with alkaline nitrogen, which can improve the conditions for the formation of brazed joints in aluminum [10-11].

Low carbon steel has good physical properties such as easy to cast, welded and other machining work. Generally, this steel is used for construction, hospital equipment, household appliances, and so on. Some equipment structures use low carbon steel pipes for basic construction, where many brazed connections are applied to connect each pipe. The joint tensile strength is 509 $\mathrm{N} / \mathrm{mm}^{2}, 2.35 \%$ higher than the base metal strength. Brazed slits of $0.5 \mathrm{~mm}$. Hardness value decreased compared to base metal, on average $18.5 \%, 18.57 \%$ in HAZ (Heat Affected Zone), and $19.81 \%$ of pipe metal below the base metal value. At $\mathrm{Cu}-\mathrm{P}$ joints, It causes a thicker $\mathrm{Cu} 3 \mathrm{P}$ layer to develop at the brazing joint when the brazing temperature rises to $620^{\circ} \mathrm{C}$ with longer holding times and increased pressure. The shear force increases with a holding time of 30 minutes and a pressure of $12.173 \mathrm{kPa}$ because this condition results in a thick $\mathrm{Cu}_{3} \mathrm{P}$ phase. This brazing connection has an average shear force of $736.27 \mathrm{~N}$ [12].

Using $\mathrm{Cu}-\mathrm{Ni}-\mathrm{Sn}-\mathrm{P}$ amorphous filler metals, Jattakul \& Kanlayasiri (2018) [23] investigated and measured the microstructure, tensile shear strength and surface fracture behaviour. When the brazing temperature reaches $680{ }^{\circ} \mathrm{C}$, this results in a maximum tensile shear value of 696.325 N. Microstructure consists of a $\mathrm{Cu}$-rich solid solution and $(\mathrm{CuNi})_{3} \mathrm{P}$ as an eutectic structure formed during brazing, and then a $\mathrm{Cu}$-rich solid solution is created around the eutectic structure as an area matrix. Fracture analysis was conducted for brazed joints, which after shear check showed ductile fractures [13].

Improving the wetting properties of aluminum metal matrix composites (Al-MMCs) (Al-SiC) is done by melting brazed alloys to produce stronger bonds. Based on this approach, Al-MMCs containing 55\% SiC materials were brazed into Fe-Ni-Co alloys successfully. Zinc-based brazing material $(\mathrm{Zn}-\mathrm{Cd}-\mathrm{Ag}-\mathrm{Cu})$ with a melting point of around $\quad 400^{\circ} \mathrm{C}$. Al-MMCs-Kovar's microscopic examination showed that nickel placing would significantly improve the reaction between liquid and composite brazing before brazing process. The fracture of the shear tested sample showed that the fracture occurred in the composite ie cohesive failure, showing good adhesion between the brazed alloy and the composite Al$\mathrm{SiC}[14]$.

Metallographic analysis revealed that, during the process of ultrasonic brazing, tin alloys formed direct contact with Al-Si-eutectic. The adhesive strength measured varies from $0.5 \mathrm{~N} / \mathrm{mm}$ to $16 \mathrm{~N} / \mathrm{mm}$ from the metallic / cell interface and from $1 \mathrm{~N} / \mathrm{mm}$ to $2 \mathrm{~N} / \mathrm{mm}$ for ultrasonic brazing connections. In addition we produce 16-cell modules consisting of cells with ultrasonic brazed contacts on the back side of $\mathrm{Al}$ and compare them to conventional modules [15].

One of the advances in shipbuilding technology is the process of coating carbon steel with copper derived from brass by the furnace brazing process. Argon gas is used to prevent steel oxidation. However, when it produces a deposit, a low gas flow rate is blown in order to remove zinc from the brass by oxidation, leaving copper deposits on the steel sheet. Diffusion has been shown to play a major role in the creation of layers. Industrial applications of such coatings can be applied in heat transfer devices because of the good thermal conductivity of copper [16]. Brass and copper alloys offer high strength and excellent strength retention at high temperatures. Both of these materials can withstand high temperature brazing processes without losing great strength [17].

Aluminum alloys 5052 and different metals namely brass H62 connected with TIG brazing using Zn-2\% Al flux. Analysis was carried out on the microstructure of the connection, the structure of the interface layer and mechanical properties. The results show that a good brazing connection is obtained, due to the excellent $\mathrm{Zn}-2 \%$ $\mathrm{Al}$ wetting ability on the brass surface. $\mathrm{AlCu}$ intermetalic 
compounds strip (IMCS) is formed in the transition zone on the brass side. Intermetallic layers of $\mathrm{Cu}_{9} \mathrm{Al}_{4}$ and $\mathrm{CuZn}$ are formed at the interface. The thickness of the interface layer and joint tensile load increases initially and then decreases with increasing heat barzing. Micro hardness in the weld area and interface layer is higher than aluminum and brass base metal. The tensile test results showed that the fracture occurred at the interface layer of the brass side [18].

Aluminum alloy 6060 coated with $\mathrm{Al}_{12} \mathrm{Si}$ alloy powder using brazing. The coated sample is heated to investigate the wetting activity of the deposited $\mathrm{Al}_{12} \mathrm{Si}$ and the diffusion mechanism between the $\mathrm{Al}_{12} \mathrm{Si}$ layer and the substratum in the air and under the argon atmosphere. The analysis shows that the $\mathrm{Al}_{12} \mathrm{Si}$ brazed alloy can enter the substrate by cold spraying. With through process temperature, the thickness of the $\mathrm{Al}_{12} \mathrm{Si}$ layer increases. The heat treatment shows that the metallurgical bond is very good between the $\mathrm{Al}_{12} \mathrm{Si}$ layer and the substrate. Without flux, coated samples can be well brazed. The thickness and width of the layer affects the brazed joint's shear strength. The maximum shear strength of the brazed links is $80 \mathrm{MPa}$ [19].

In the brazing process, the aluminum content of the Sn$0.7 \mathrm{Cu}-\mathrm{xAl}$ alloy $(\mathrm{x}=0-0.075)$ affects the microstructure and mechanical properties of the joint. The microstructure of the $\mathrm{Sn}-\mathrm{Cu}$ brazed alloy was perfected by Al. For $\mathrm{Sn}-\mathrm{Cu}-$ Al brazed alloys, intermetallic compounds (IMCs) range from $\mathrm{Cu}_{6} \mathrm{Sn}_{5}$ for Sn-Cu- (0.01-0.025) to $\mathrm{Al}_{2} \mathrm{Cu}$ in $\mathrm{Sn}$ $0.7 \mathrm{Cu}-(0.05-0.075) \mathrm{Al}$. For rising aluminum concentration, the IMCs and the eutectic volume fraction increase. Aluminum can increase the wettability of $\mathrm{Sn}-\mathrm{Cu}-\mathrm{Al}$ brazed alloys. Sn-0.7Cu-0.075Al's distribution coefficient is $70 \%$. The $\mathrm{Sn}-\mathrm{Cu}-\mathrm{Al}$ alloy's tensile strength decreases after

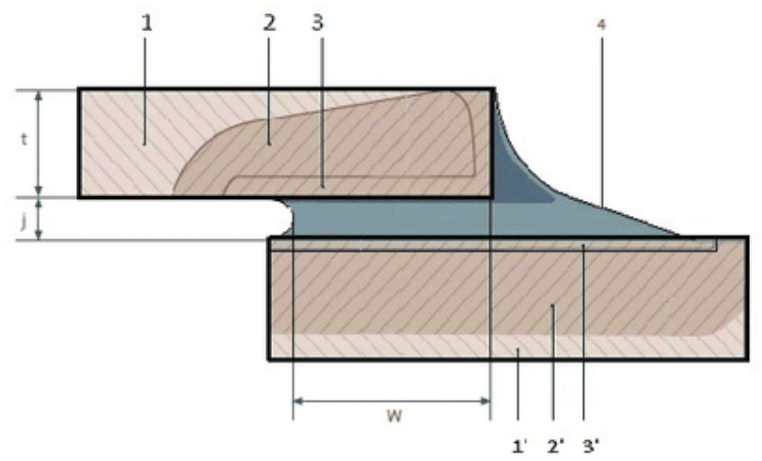

Figure 1: Illustration of Lap Lap Joint [22]

Connection strength is tested by tensile testing. Micro structure was analyzed using macro, micro, SEM (Scanning Electron Microscope) and EDX (Energy Dispersive X-Ray) photographs. aluminum rises by weight by $0.025 \%$ and then increases by weight when aluminum adds $0.075 \%$ due to IMC variations and $\mathrm{Al}_{2} \mathrm{Cu} / \mathrm{Sn}$ eutectic volume fraction of high microhardness. $\mathrm{Sn}-0.7 \mathrm{Cu}-0.075 \mathrm{Al}$ 's mechanical properties strengthen with the fineness of the microstructure. Sn$0.7 \mathrm{Cu}-0.075 \mathrm{Al}$ is a lead-free brazed alloy that is optimized for copper substrates [20].

Aluminum joints can be made by brazing with other metals such as copper, steel and alloy steel. Nonetheless, the binding of these materials is correlated with many problems caused by the variable physical and chemical properties of the metal to be bound. There is also a possibility of a violent intermetallic process that causes the braking of fragile joints. How to restrict the incidence of intermetallic phases at the aluminum-to-other metal interface is achieved through galvanic application on the $\mathrm{Zn}-\mathrm{Ni}$ coating surface [21]. The goal of this analysis was to determine the strength of the shear tensile and the strength of the aluminum and brass joints by means of the brazing process.

\section{RESEARCH METHOD}

This research uses $3 \mathrm{~mm}$ thick aluminum and brass plate material. The brasing process is carried out using alusol filler material. The type of connection made is the but joint. The making of the connection specimen is based on the ASME IX standard, namely the width of the specimen is $20 \mathrm{~mm}$, the length is $160 \mathrm{~mm}$ for one side and the length of the shear area is $20 \mathrm{~mm}$.

The names of the metal parts in the brazing process can be

Information on the brazed area:

1. 1. Base metal

2. 2. HAZ

3. 3. Diffusion zone

4. 4. Braze metal classified as shown in Figure 1. 


\section{RESULTS AND DISCUSSION}

The results of joining the brazing between aluminum and brass can be seen in Figure 2 (a). Specimens after tensile testing are shown in Figure 2 (b). Based on observations with the eyes, the results of broken fractures revealed several void deffects. That can be caused by imperfect flow of filler material. The filler material cannot fill the cavity between aluminum and brass so that the void is formed. Another factor affecting the formation of void defects is the use of fluxes. Flux does not perfectly wet the aluminum and brass surfaces. Flux material is not working optimally so that material flow is blocked.

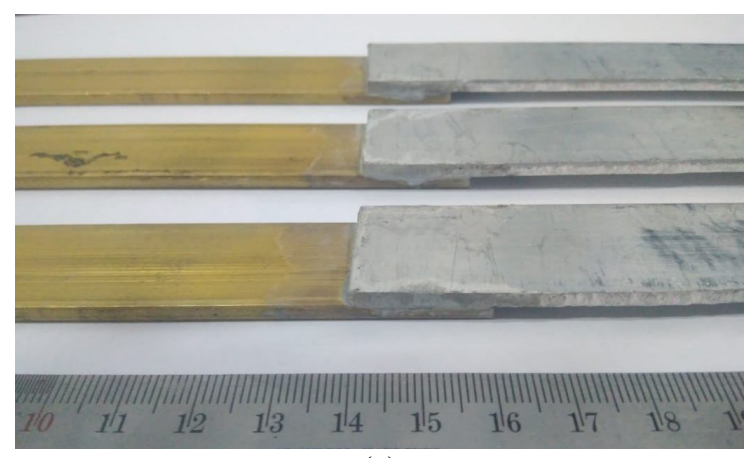

(a)

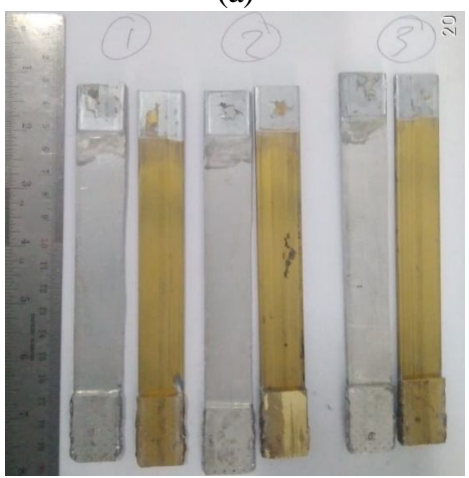

(b)

Figure 2: Brazed brass and aluminum before (a) and after (b) tensile test.

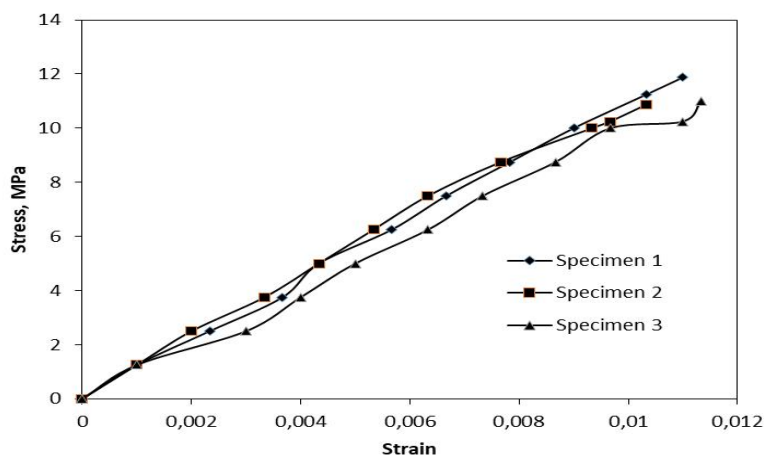

Figure 3: Shear tensile test results.

Tensile test results are shown in Figure 3. There are three tensile test specimens and all give similar results. Based on the stress-strain image formed, it can be said that the type of material is brittle. The highest average stress was obtained at
12.6 N/mm ${ }^{2}$ and 0.011 for the highest strain. Young's modulus calculation is obtained $1.183 \mathrm{kN} / \mathrm{mm}^{2}$.

The fracture after tensile stress is influenced by the properties of the filler material (alusol) and the properties of intermetalic in the brazed junction area. In the results of research specimens that occur fractures in the alusol (braze metal) that meet brass. Tensile testing of all specimens shows the results of fractures occurring at the brazed area. Therefore, the material formed from alusol becomes brittle material. The material with brittle properties could be intermetallic compounds.

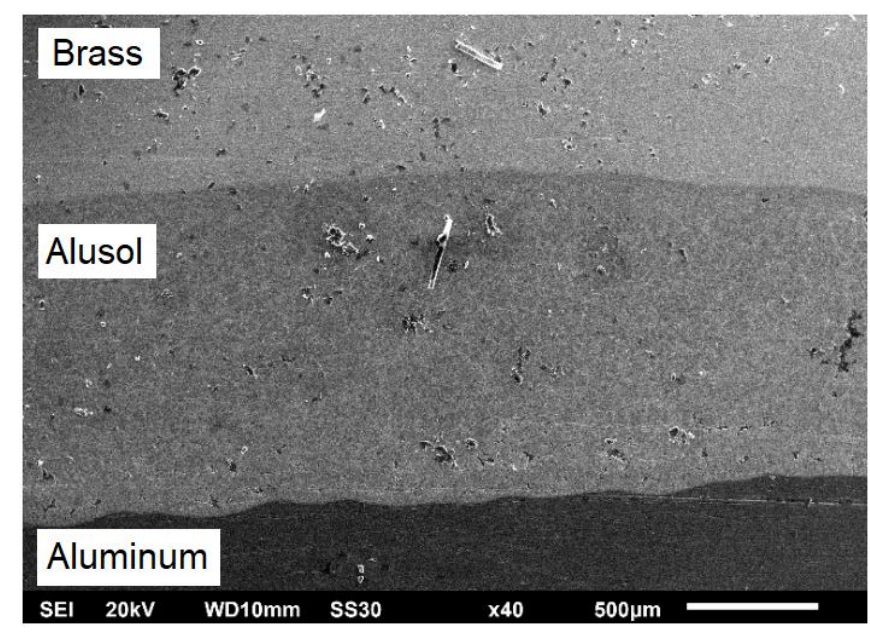

Figure 4: SEM image of brass, alusol and aluminum layers.

Micro photo analysis was carried out by using SEM image as shown in Figure 4. Based on Figure 4, the brazed joint between aluminum and brass can be formed properly using alusol filler material. The joining looks homogeneous and no defects appear at $\mathrm{x} 40$ magnification.

Micro photo analysis was continued at the brass material boundary with alusol. The way is carried out by zooming the image to the magnification x500 as shown in Figure 5(a). From the picture, it can be seen several voids and worm holes defects. More defects were seen in the alusol layer than the brass layer. Figure 5(b) shows void defects and worm holes more clearly with x2000 magnification. Based on the SEM image data, it further reinforces the reasons for failure in the brazed area during tensile test.

Micro photo analysis on the layer between aluminum and alusol was also carried out to determine visible defects. Figure 6 (a) shows the layer between aluminum and alusol with x500 magnification. Some void defects have been seen in the alusol layer. The x 2000 magnification is shown in Figure 6 (b) to show the clearer boundaries of the two materials. Based on Figure 6 (b) it can be said that many voids and worm hole defects occur in the alusol layer.

The interface boundary layer between the filler material and the brass appears to be fused. This shows that the interface between the two materials is very good. Interdiffusion between elements occurs in the interface due to the 
concentration of the gradient. But the interdifusion layer is not clearly visible. Alusol which is made from aluminum has a low melting point and good flowability as a filler metal. Therefore it can be said that in the brazing process, the flow capability of the filler material is influenced by the height of the filllet and the width of the gap between aluminum and brass.

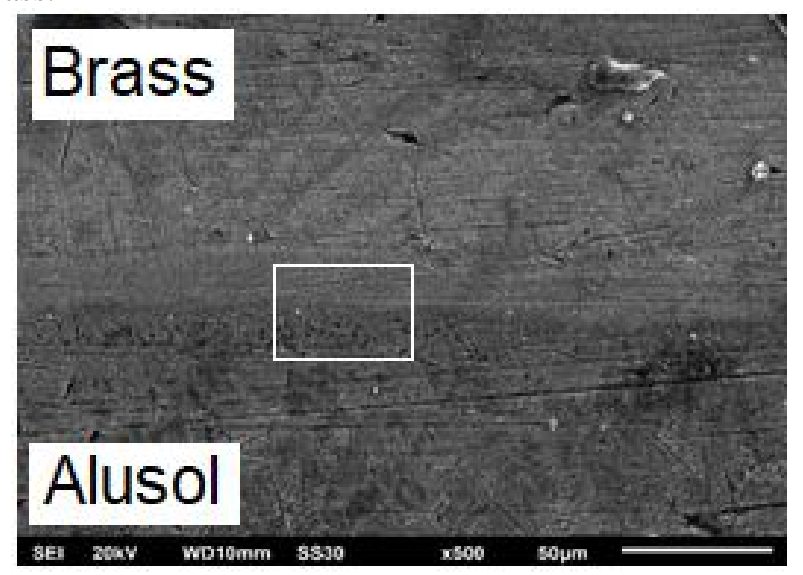

(a)

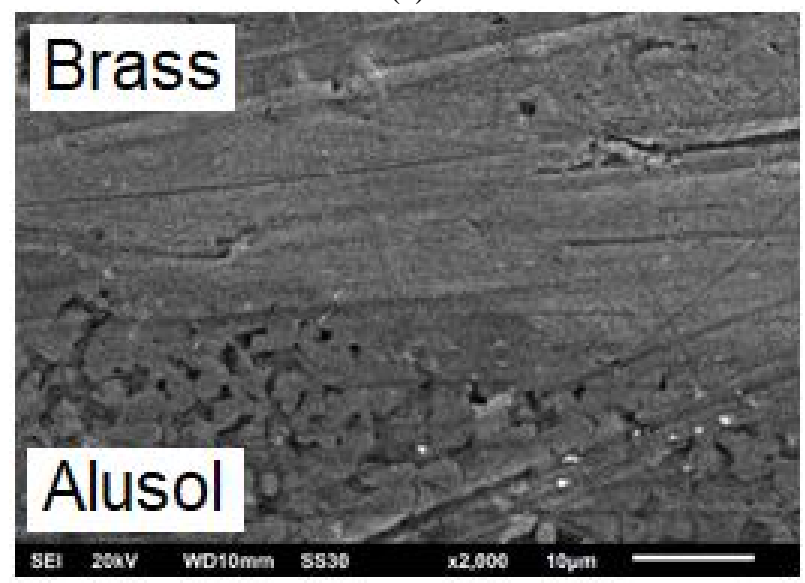

(b)

Figure 5: Interface of brass and alusol.

Figure 7 shows the chemical composition produced from EDX. Based on the EDX test, the five highest elements are $\mathrm{O}, \mathrm{C}, \mathrm{Al}, \mathrm{Cu}$ and $\mathrm{Zn}$. Analysis of the compounds formed in the brazing process was carried out by using the ZAF method as shown in Figure 8. Investigation of the compound using the ZAF method, although no standards have been used, has proven to provide accurate results. According to the results of the quantitative analysis, it appears that the braze region consists of a solid solution based on $\mathrm{C}$ (carbon), $\mathrm{Al}_{2} \mathrm{O}_{3}$ (Alumina), $\mathrm{CuO}$ (copper $\mathrm{II}$ oxide) and $\mathrm{ZnO}$ (Zinc Oxide). The intermetallic formation between brass and alusol produces a thin layer, which is also a solid solution, observed at the interface between the brass and the filler (alusol). When alusol is deposited on $\mathrm{Cu}-\mathrm{Zn}$ (brass alloy), the reaction layer is only 5-30 $\mathrm{nm}$ at the interface [3]. Therefore, no reaction layer is seen at the interface because the reaction layer is too thin. In addition, the picture clearly shows the existence of hollow circles (porous) which can reduce the tensile strength of the brazing joint.

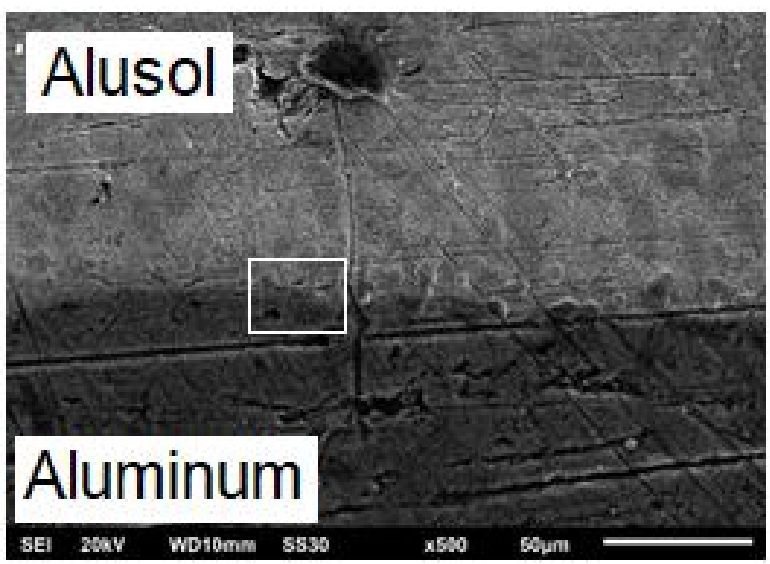

(a)

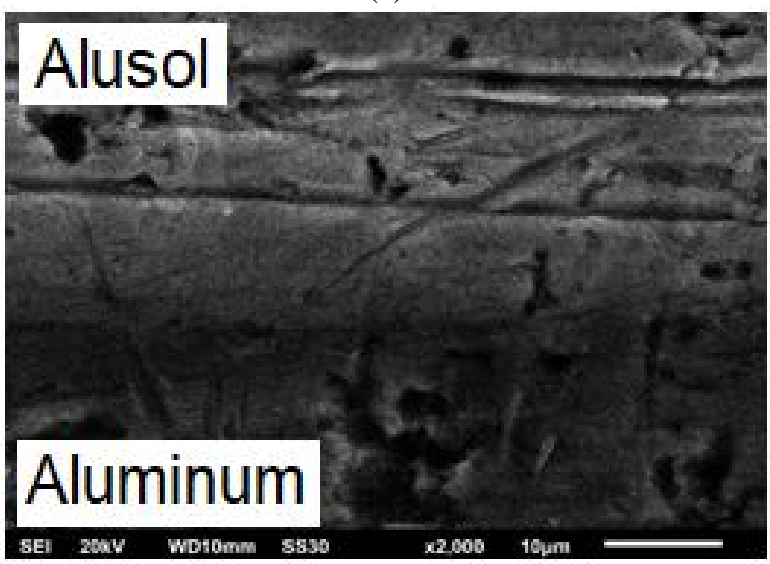

(b)

Figure 6: Interface of aluminum and alusol.

\section{CONCLUSION}

Brazed joint between aluminum and brass with $350 \mathrm{~mm}^{2}$ of shear area was broken when pulled with a load of $4.410 \mathrm{kN}$. The brazed specimen has a maximum tensile stress, strain and Young modulus of $12.601 \mathrm{~N} / \mathrm{mm}^{2}, 0.011$, and 1.183 $\mathrm{kN} / \mathrm{mm}^{2}$ respectively. From the micro photo analysis, porous microstructure was detected in the brazed line facing to the brass side. The chemical compound of brazed area was contained Carbon (C), Alumina $\left(\mathrm{Al}_{2} \mathrm{O}_{3}\right)$, Copper (II) Oxide $(\mathrm{CuO})$ and Zinc Oxide $(\mathrm{ZnO})$. The composition was $21.53 \%$, $37.20 \%, 13.63 \%$, and $27.64 \%$ respectively. 


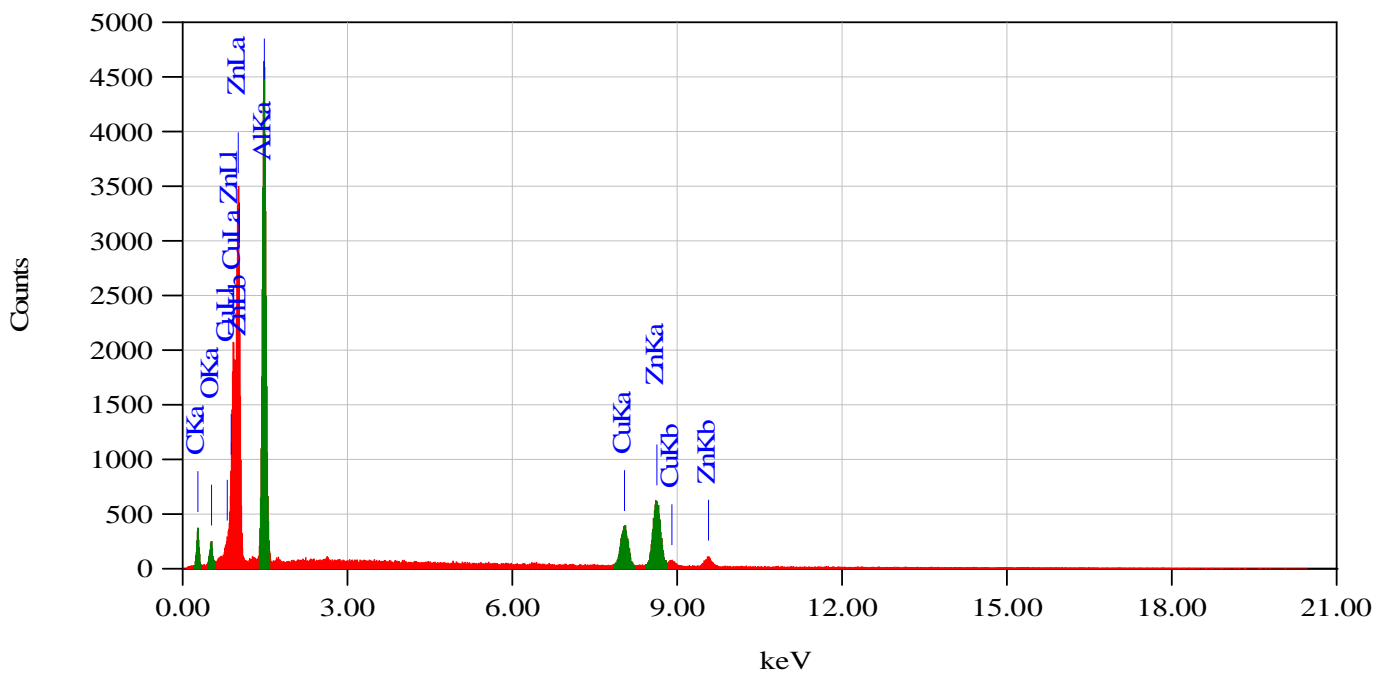

Figure 7: EDX results of chemical compositions.

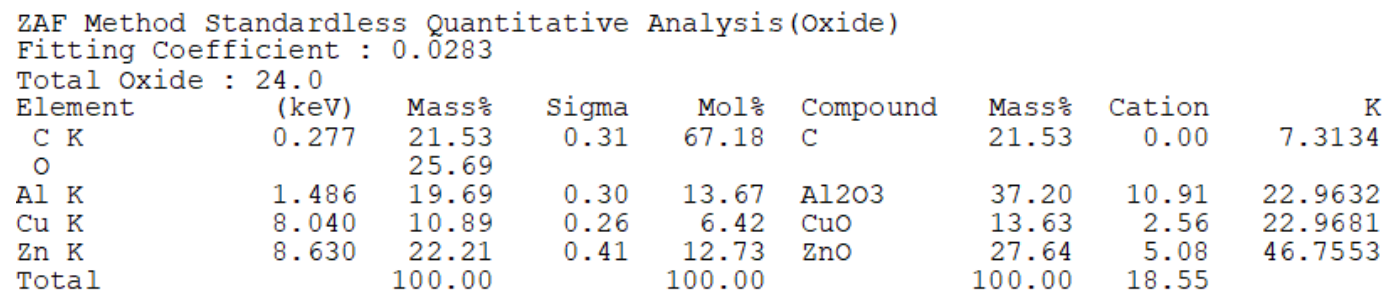

Figure 8: ZAF method standardless quantitative Analysis.

\section{REFERENCES}

1. Lucas Milhaupt. (2004). The Brazing Book. Lucas Milhaupt.

2. Möller, F., Grden, M., Thomy, C., \& Vollertsen, F. (2011). Combined laser beam welding and brazing process for aluminium titanium hybrid structures. Physics Procedia, 12(PART 1), 215-223. https://doi.org/10.1016/j.phpro.2011.03.028.

3. Cao, J., Zhang, L. X., Wang, H. Q., Wu, L. Z., \& Feng, J. C. (2011). Effect of Silver Content on Microstructure and Properties of Brass/steel Induction Brazing Joint Using Ag-Cu-Zn-Sn Filler Metal. Journal of Materials Science and Technology, 27(4), 377-381. https://doi.org/10.1016/S1005-0302(11)60077-7.

4. Ostafin, M., Balkenhol, M., Erlemeyer, J., \& Köhler, M. (2010). Self-brazing aluminium clad steel. Materialwissenschaft Und Werkstofftechnik, 41(11), 946-950. https://doi.org/10.1002/mawe.201000689.

5. Prach, M., \& Koleňák, R. (2015). Brazinging of copper with high-temperature Zn-based brazings. Procedia Engineering, 100(January), 1370-1375. https://doi.org/10.1016/j.proeng.2015.01.505.

6. Ahmed, E. and Abduljalil, H. M. (2019) 'Effect of NH2 substituent group on PC61BM properties using DFT', International Journal of Emerging Trends in Engineering Research, 7(8), pp. 183-190. doi: 10.30534/ijeter/2019/13782019.

7. Movahedi, M., Kokabi, A. H., \& Madaah Hosseini, H. R. (2009). An investigation on the brazinging of $\mathrm{Al}$
3003/Zn sheets. Materials Characterization, 60(5), 441-446.

8. Saida, K., \& Nishimoto, K. (2011). Laser brazing of aluminium to steels. Welding International, 25(6), 430440. https://doi.org/10.1080/09507111003655515.

9. Markovits, T., Takács, J., Lovas, A., \& Belt, J. (2003). Laser brazing of aluminium. Journal of Materials Processing Technology, 143-144(1), 651-655. https://doi.org/10.1016/S0924-0136(03)00310-8.

10. Khorunov, V. F., \& Sabadash, O. M. (2013). Brazing of aluminium and aluminium to steel. Advances in Brazing: Science, Technology and Applications. Woodhead Publishing Limited.

11. Julianto, E., Siswanto, W. A. and Effendy, M. (2019) 'Characteristics of Temperature changes and Stress of Float Glass', International Journal of Emerging Trends in Engineering Research, 7(9), pp. 228-233. https://doi.org/10.30534/ijeter/2019/03792019

12. Hayashi, J., Miyazawa, Y., Satpathy, M. P., \& Das, K. (2018). Influences of solid-state brazing conditions on microstructure and tensile shear force of $\mathrm{Ag}-\mathrm{Cu}-\mathrm{P}$ brazed copper sheets Influences of solid-state brazing conditions on microstructure and tensile shear force of $\mathrm{Ag}-\mathrm{Cu}-\mathrm{P}$ brazed copper sheets.

13. Muda, M. F. et al. (2019) 'Mechanical Behaviour of Mortar Made with Washed Bottom Ash as Sand Replacement', International Journal of Emerging Trends in Engineering Research, 7(9), pp. 7-14. https://doi.org/10.30534/ijeter/2019/09792019

14. Lu, J., Mu, Y., Luo, X., \& Niu, J. (2012). Short 
communication A new method for brazinging particlereinforced aluminum metal matrix composites. Materials Science \& Engineering B, 177(20), 17591763. https://doi.org/10.1016/j.mseb.2012.08.001.

15. Schmitt, P., Eberlein, D., Ebert, C., Tranitz, M., Eitner, U., \& Wirth, H. (2013). Adhesion of Al-metallization in ultra-sonic brazinging on the Al-rear side of solar cells. Energy Procedia, 38, 380-386. https://doi.org/10.1016/j.egypro.2013.07.293.

16. Molleda, F., Mora, J., Molleda, J. R., Carrillo, E., Mora, E., \& Mellor, B. G. (2008). Copper coating of carbon steel by a furnace brazing process using brass as the braze. Materials Characterization, 59(5), 613-617. https://doi.org/10.1016/j.matchar.2007.05.005.

17. Shabtay, Y. L., Ainali, M., \& Lea, A. (2004). New brazing processes using anneal-resistant copper and brass alloys, 25(03), 83-89. https://doi.org/10.1016/S0261-3069(03)00162-6.

18. Zhou, L., Li, Z.-Y., Zhao, H.-Y., Xie, Y., Huang, Y.X., \& Feng, J.-C. (2015). Microstructure and mechanical properties of $\mathrm{Al} / \mathrm{brass}$ dissimilar metals TIG welding-brazing joint. Zhongguo Youse Jinshu Xuebao/Chinese Journal of Nonferrous Metals, 25(9). https://doi.org/10.12073/j.hjxb.2018390123.

19. Bobzin, K., Zhao, L., Schlaefer, T., \& Warda, T. (2010). Influence of the filler materials on flux-free brazing of pure aluminium (1050). Frontiers of Mechanical Engineering in China, 5(1), 47-51. https://doi.org/10.1007/s11465-009-0079-9.

20. Yang, L., Zhang, Y., Du, C., Dai, J., \& Zhang, N. (2015). Effect of aluminum concentration on the microstructure and mechanical properties of $\mathrm{Sn}-\mathrm{Cu}-\mathrm{Al}$ brazing alloy. Microelectronics Reliability, 55(3-4), 596-601. https://doi.org/10.1016/j.microrel.2014.12.017.

21. Mirski, Z., Wojdat, T., \& Stachowicz, M. (2015). Brazinging of aluminium with copper and steel using intermediate layer $\mathrm{Zn}-\mathrm{Ni}$. Archives of Civil and Mechanical Engineering, 15(4), 903-910. https://doi.org/10.1016/j.acme.2015.02.008.

22. Voiculescu, I. (2017). Brazing Behaviour of $\mathrm{Ag}-\mathrm{Cu}$ Filler Materials. Recent Progress in Brazinging Materials. https://doi.org/10.5772/intechopen.69862.

23. Jattakul, P., \& Kanlayasiri, K. (2018). Effects of brazing parameters on the microstructure and tensile shear force of copper sheets using amorphous filler metal, $01010(20), 0-3$.

https://doi.org/10.1051/matecconf/201819201010 